\title{
Tele-Otolaryngology at a Tertiary Care Center in North India During COVID-19 Pandemic Lockdown: A Validated Patient Feedback Questionnaire Based Study
}

\author{
Ramya Rathod ${ }^{1} \cdot K^{2}$ anika Arora ${ }^{1} \cdot$ Karthika Chettuvati $^{1}$ - Sajith Abraham ${ }^{1}$. \\ Prerna Angrish $^{1}$ - Vikas Sharma ${ }^{1}$ - Ganesh Agarwal ${ }^{1}$ - Manjul Muraleedharan ${ }^{1}$. \\ Reshma Raj ${ }^{1} \cdot$ Naresh K. Panda $^{1} \cdot$ Jaimanti Bakshi $^{1} \cdot$ Satyawati Mohindra $^{1}$. \\ Rijuneeta Gupta $^{1} \cdot$ Roshan Verma $^{1} \cdot$ Sandeep Bansal $^{1}$ - Anurag Ramavat ${ }^{1}$. \\ Gyanaranjan Nayak $^{1}$ - Sourabha K. Patro ${ }^{1} \cdot$ Ashok Kumar $^{2} \cdot$ Ramandeep S. Virk $^{1}$ (1)
}

Received: 29 April 2021/Accepted: 24 May 2021/Published online: 4 June 2021

(C) Association of Otolaryngologists of India 2021

\begin{abstract}
Providing medical care using the telecommunication networks holds the promise of increased access and efficiency of healthcare particularly during global emergencies like the Coronavirus disease 2019 (COVID-19) pandemic. Most of the hospital setups worldwide have put telemedicine into practice ever since the onset of the COVID-19 pandemic. This study aimed at assessing the effectiveness of Tele-otolaryngology (TO) at a tertiary care centre during the pandemic lockdown. A validated patient feedback questionnaire was developed and distributed to 2577 patients who utilised the TO mobile health service at our institute. Patient feedback-based assessment of TO effectiveness during COVID-19 lockdown was carried out. The validated questionnaire in English and Hindi was statistically robust with Cronbach's alpha value of 0.808 and 0.886 respectively. 1751 patients completed their feedback to the questionnaire. 97.5\% utilised WhatsApp for TO consultation. $15.2 \%$ patients were detected of Severe acute respiratory syndrome Coronavirus 2 (SARS$\mathrm{CoV}-2$ ) infection with TO guidance. Up to $75 \%$ patients had a positive response to the questionnaire and $91.1 \%$ opined of savings achieved either with travel time, cost incurred or the treatment time. With respect to patient health status, $71.5 \%$ recovered, $20.1 \%$ had no change and $8.4 \%$ deteriorated with a mortality rate of $1.65 \%$. Telehealth in otolaryngology during the COVID-19 pandemic
\end{abstract}

Ramandeep S. Virk

virkdoc@hotmail.com

1 Department of Otolaryngology, Head and Neck Surgery, Postgraduate Institute of Medical Education and Research, Chandigarh, India

2 Department of Neurology, Postgraduate Institute of Medical Education and Research, Chandigarh, India lockdown was indispensable in managing exigencies. Redesigning of clinical protocol and technical constraints, clinician training and a validated patient feedback questionnaire would effectively bestow upon the global emergencies.

Keywords Tele-otolaryngology · COVID-19 · Lockdown · Mobile health · Questionnaire

\section{Introduction}

Coronavirus disease 2019 (COVID-19) pandemic had drastically changed the existing robot programmed health care system in India where the patient load, disease burden and its associated morbidity and mortality are very high. The centers of excellence and the tertiary health care centers in the country play a leading role in organized, planned and programmed addressal of the patient load. However, the unplanned, sudden implementation of lockdown due to outbreak of Severe acute respiratory syndrome Coronavirus 2 (SARS-CoV-2) pandemic throughout the country had compromised the robot programmed healthcare facilities. Ability to adapt to the changing scenarios is the hallmark of human evolution and telemedicine hospital services have given hope and promising results to the patients' problem during the pandemic. Telemedicine has been in practice since the past 2 decades worldwide. Patient-doctor interaction via technology like telephone, mobile phone, computer video/audio calling, television video calling, exchange of medical records and reports through mail or fax have been effectively exercised by primary or secondary health care services and remote areas with limited health facilities for procuring expert opinion from centers of excellence or tertiary health care centers in 
developed countries, developing and underdeveloped countries. Literature on tele health care reflects on their ability to effectively address the patient problems and provide constructive guidance to seek specialist care whenever appropriate [1]. These services considerably contributed to the public health care in crisis situations like the ongoing COVID-19 pandemic during which the elective hospital services like the out-patient facility, operative set-ups, laboratories and investigative set-ups were all halted suddenly for approximately 3 months in India i.e., mid-March to mid-June of the complete lockdown period during which only the emergency services were functional on priority basis. Existing evidence of telehealth during COVID-19 pandemic times shows that various medical and surgical specialties have undertaken the telemedicine services and their outcomes in terms of patient care, guidance, home-based care, monitoring and patient satisfaction have been analyzed. [2-4] We layout our experience with Teleotolaryngology (TO) service in practice at our institute during the COVID-19 lockdown by developing a validated patient feedback questionnaire.

\section{Materials and Methods}

The study was conducted in the Department of Otolaryngology, Head and Neck Surgery, Postgraduate Institute of Medical Education and Research (PGIMER), Chandigarh, India in collaboration with the Medical records department (MRD) of the institute between October, 2020 to January, 2021 and the principal investigators and the co-investigators of the study included the faculty, senior registrars and the postgraduate trainees of the department who participated in rendering the TO during the COVID-19 lockdown period in the department. Institutional ethics committee approval was taken prior to beginning of the study with approval number "NK/6817/Study/185".

\section{*Patient Record Retrieval}

A total of 2577 patient registrations were made for the teleotolaryngology services of the institute between the duration of May to July, 2020. The details of these registered patients like the name, age, registration number and the contact telephone number were retrieved from the institutional MRD.

\section{*Development of questionnaire (Fig. 1)}

A thorough literature review of the telemedicine questionnaires was done and a staged development of the final questionnaire was executed by the principal investigators and the co-investigators of this study to inculcate attributes like usefulness, ease of use, doctor-patient interaction quality, effectiveness in coping with pandemic, patient satisfaction with the tele-otolaryngology services [5-9]. In the first stage, the investigators developed an English questionnaire in four subsections namely 'the general information' which included patient demographics like name, age, gender, residence, educational qualifications and guardian assistance for the tele-consultation; 'access to care' which included questions on mode of accessing this service; 'communication and information' that dealt with patients experience in registering for tele-otolaryngology consultation and patient-doctor interaction and patient satisfaction' which was the most significant part of this questionnaire.(ANNEXURE I) The patient satisfaction forum included eleven items with five responses for each item graded over a Likert scale of 1 to 5 with 1 and 2 being negative responses, ' 3 ' being a neutral response and 4 and 5 being positive responses [10]. The pilot questionnaire was applied to $5-10 \%$ patients of total sample and their feedback was collected, compiled, analyzed and the 11 items of the satisfaction forum were subjected to reliability and internal consistency testing using the Cronbach's alpha test. All the investigators who applied the pilot questionnaire to the patients opined for inclusion or exclusion of each item under the four subsections. The items which scored more than $50 \%$ of investigators positive response were included and that which scored less than $50 \%$ of investigators positive response were excluded from the questionnaire. Following initial validation and investigator inclusion-exclusion by majority, a second version of the English questionnaire was developed which had the first three subsections of the pilot version merged into a common part and the 11 items of the satisfaction part were consolidated into 9 items to avoid similarity and repetitiveness of the items. This version was further subjected to language cross check by two English language experts and an expert opinion on ease of usage of the questionnaire by two patients well versed with English language who never utilized the telemedicine service. The resultant questionnaire was applied to up to 5\% patients of total sample, their responses to the questionnaire was collected, compiled, analyzed and the items on satisfaction forum of the questionnaire were validated. Once validated, the English questionnaire was translated into Hindi, the national language of India, by a language expert and it was applied to up to $5 \%$ of the total patient sample and the data collected was compiled, translated to English, analyzed and the satisfaction forum was validated. With satisfactory reliability achieved for the Hindi version, a final English and Hindi versions of the questionnaire were concluded. (ANNEXURE II and III). 
Fig. 1 Flow diagram on the study methodology

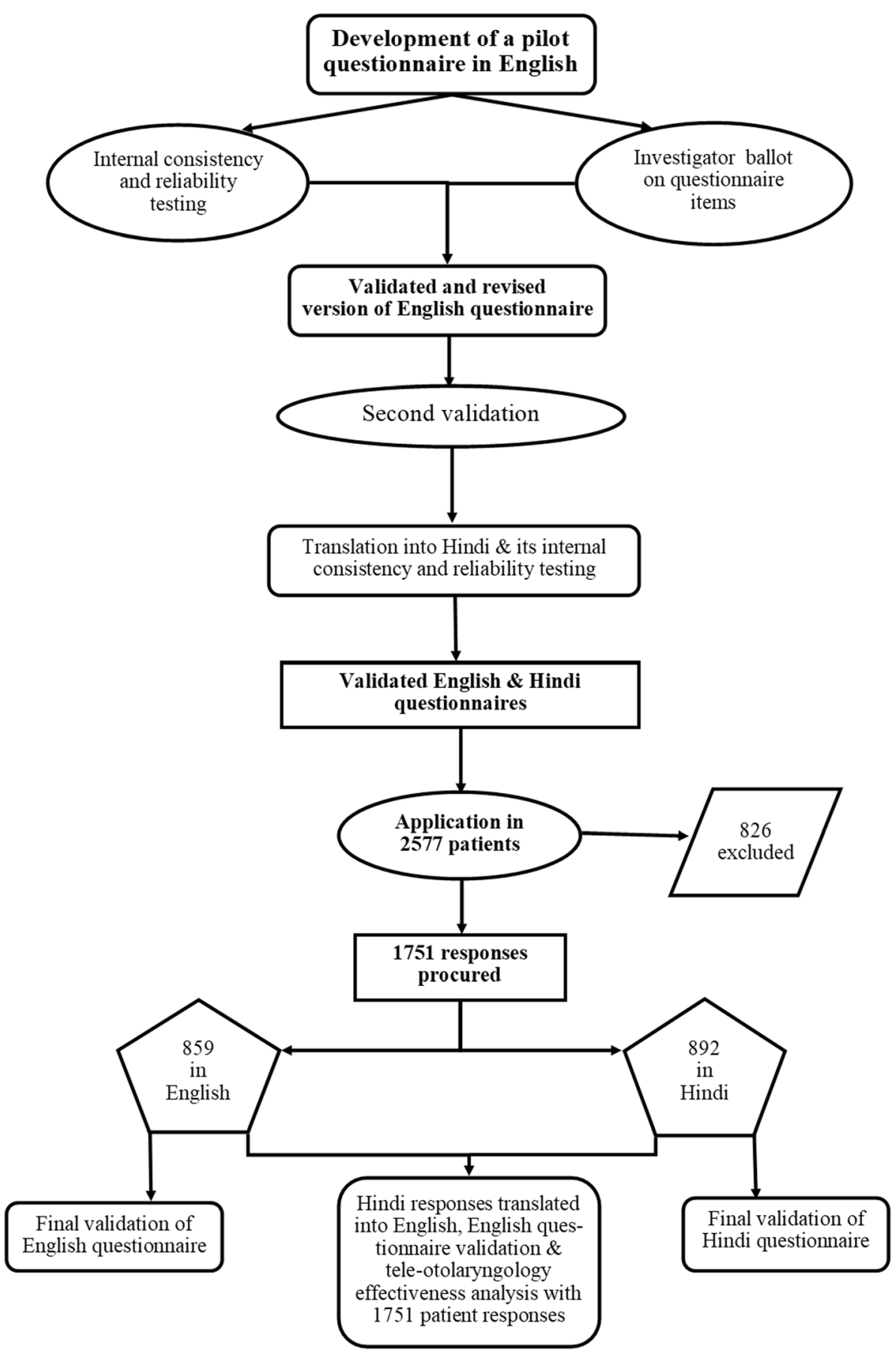

\section{*Procuring Patient Feedback}

The finalized English and Hindi versions of questionnaire were utilized to take patient or their attendant/guardian feedback on the tele-otolaryngology services. The total patient registrations were equally divided among the investigators. Every investigator contacted the patient through the registered telephone number. The investigator kept himself/herself blinded from the patient by introducing themselves as a research and development trainee at
PGIMER instead of revealing their identity to the patient as an ear, nose and throat (ENT) clinician which would bias their response. After a brief introduction of the study and its purpose in improving the telemedicine facility at the institute, a verbal consent of the patient and/or their guardian was taken following which the investigator proceeded in procuring their feedback.

Patients who were willing to give their feedback were questioned for their language preference whether English or Hindi and the best possible way to procure their 
feedback was asked i.e., patients were offered different ways in giving their feedback like (1) a portable document format (PDF), Microsoft word document or joint photographic expert group (JPEG) format of the questionnaire was sent to their mobile via the most commonly used Android smartphone mobile application (app) "WhatsApp"; (2) a google link was produced and shared with the patient on WhatsApp or email or as a text message to access the questionnaire; and (3) the investigator contacting the patient reads out and explains the questionnaire items to get an appropriate patient response. English and Hindi patient responses to questionnaire were segregated by the investigator for analysis. For total sample size cumulative analysis, the patient responses in Hindi were translated to English. A final collation of the data compiled by each investigator was done for statistical analysis.

\section{*Statistics and Telemedicine Effectiveness Analysis}

A statistical package, International business machinesstatistical package for the social sciences version 22.0 (IBM SPSS) was used to analyze data in our study. Normal distribution of the continuous data was checked by using Shapiro-Wilk test. Mean and standard deviation (SD) was calculated for normally distributed continuous variables whereas median and Inter quartile range (IQR) were calculated for skewed data. Frequencies and percentage were calculated for categorical data. Two tailed $\mathrm{p}$ value $<0.05$ was considered statistically significant with $95 \%$ confidence interval. The patient responses obtained for the English and Hindi feedback questionnaires were subjected to the internal consistency testing using Cronbach's alpha where the alpha value between 0.7 to 0.8 indicated an acceptable rate, 0.8 to 0.9 indicated good and $>0.9$, an excellent rate of internal consistency [11]. Cronbach's alpha test is a statistical method which checks for the degree of common information that share the items of a scale measurement. Value above 0.7 indicated appropriate internal consistency. The reliability was tested by temporal stability test where the intra-class correlation co-efficient was calculated and a value $>0.75$ was considered good and $>0.9$ considered excellent [12]. The Exploratory factor analysis was performed by Keyser-Meyer-Olkin test where value $>0.5$ indicated appropriate to do the factor analysis and Bartlett sphericity test where $\mathrm{p}<0.05$ indicated it is pertinent to make a factor analysis [9]. Three different criteria were used to check for the number of different dimensions of the questionnaire (1) Kaiser rule which selects the number of factors with a value greater than $1 ;(2)$ the percentage of explained variance which is determined by the accumulated percentage of variation extracted in each factor (varimax rotation with Kaiser's normalization was used to simplify the number of dimensions); (3) a scree plot which graphically represents the number of factors or dimensions extracted, we retained the factors or components to the left of the inflection point on the graph [13].

The patient responses to each item of satisfaction forum were summated to percentage of negative, neutral and positive response. The cumulative percentage of scores 1 and 2 was negative response, 3 was a neutral response whereas 4 and 5 were the positive responses. The negative and positive response percentages were compared to analyse the effectiveness of tele-otolaryngology facility. Exception for this comparison was item ' 3 ' of the questionnaire which dealt with savings in terms of time, money and frequency of travel achieved by the patient by use of this service and was analysed separately.

\section{Results}

The pilot questionnaire was applied to 130 patients $(5 \%)$ and the responses were subjected to validation. The overall alpha coefficient was 0.931 (95\%, CI: 0.911-0.947) and the intraclass correlation co-efficient was 0.895 (95\%, CI: 0.846-0.933). Validated pilot questionnaire was applied to 53 patients $(2.05 \%)$ and on second validation of English questionnaire, the overall Cronbach's alpha was 0.905 (95\%, CI: 0.846-0.932) and the intraclass correlation coefficient was 0.931 (95\%, CI: 0.912-0.947). Hindi version questionnaire was applied to 50 patients $(1.94 \%)$ and on validation the overall alpha coefficient was 0.942 (95\%, CI: $0.912-0.962$ ) and the intraclass correlation co-efficient was 0.938 (95\%, CI: 0.909-0.961). With the alpha value $>0.9$ suggesting an excellent internal consistency, the questionnaire in English and Hindi were concluded as valid and reliable for their use to rest of the patient sample.

Out of the 2577 total patient registrations, 1751 responses to the feedback questionnaire were obtained and 826 registrations were excluded due to three reasons (i) repetitive registrations $(\mathrm{n}=566,68.5 \%)$ (ii) the patient/guardian could not be contacted with the registered phone number due to technical problems like connectivity issues ( $\mathrm{n}=205,24.8 \%$ ), and (iii) the patient/guardian were not willing for giving their feedback for reasons unknown or dissatisfied with health service or death of the patient $(\mathrm{n}=55,6.6 \%)$.

Of the 1751 patient responses, 892 patients $(50.9 \%)$ responded to the Hindi version of the questionnaire whereas 859 patients $(49.05 \%)$ responded to the English questionnaire. Out of the 1751,1103 patients $(62.99 \%)$ were males and 648 patients $(37 \%)$ were females. The mean age with SD of the patients was $42.5 \pm 17.9$ years. The other demographic details like the place of residence, highest education qualification of the patient and the 
general information pertaining to otolaryngology subspeciality, type of consultation, and the language of communication are shown in Table 1. Waiting time was $>15 \mathrm{~min}$ for 966 patients $(55.2 \%)$ and $<15$ min for 785 patients $(44.8 \%)$. After a successful online or telephone registration for the teleconsultation service, 1665 patients (95.1\%) received a call from the doctor and 86 patients (4.9\%) did not receive a call. Communication with the doctor was clear for 1716 patients (98\%) and was not clear for 35 patients (2\%). The mobile application "WhatsApp" was used by 1708 patients $(97.5 \%)$ whereas 43 patients $(2.45 \%)$ took the consultation by a direct phone call due to unavailability of smart phone or lack of access to WhatsApp. 630 patients $(35.9 \%)$ out of 1751 were detected

Table 1 Demographic details of patients

\begin{tabular}{|c|c|c|c|c|}
\hline S. no. & Variable & $n=1751$ & $(\%)$ & $p$ value \\
\hline \multirow[t]{15}{*}{1} & State of residence & & & \multirow{15}{*}{0.0001} \\
\hline & Punjab & 680 & 38.8 & \\
\hline & Chandigarh & 345 & 19.7 & \\
\hline & Haryana & 253 & 14.4 & \\
\hline & Himanchal Pradesh & 152 & 8.7 & \\
\hline & Uttar Pradesh & 118 & 6.7 & \\
\hline & Bihar & 58 & 3.3 & \\
\hline & Jammu \& Kashmir & 50 & 2.9 & \\
\hline & Uttarakhand & 33 & 1.9 & \\
\hline & Rajasthan & 29 & 1.6 & \\
\hline & Jharkhand & 19 & 1.08 & \\
\hline & Madhya Pradesh & 5 & 0.3 & \\
\hline & Gujarat & 4 & 0.22 & \\
\hline & Maharashtra & 4 & 0.22 & \\
\hline & Nepal & 1 & 0.06 & \\
\hline \multirow[t]{7}{*}{2} & Highest educational qualification & & & \multirow{7}{*}{0.0001} \\
\hline & Postgraduate & 95 & 5.4 & \\
\hline & Graduate & 413 & 23.6 & \\
\hline & Senior secondary & 384 & 21.9 & \\
\hline & Matric & 328 & 18.7 & \\
\hline & Schooling & 345 & 19.7 & \\
\hline & Uneducated & 186 & 10.6 & \\
\hline \multirow[t]{7}{*}{3} & Sub-specialty & & & \multirow{7}{*}{0.0001} \\
\hline & Ear & 361 & 20.6 & \\
\hline & Nose & 403 & 23 & \\
\hline & Throat & 480 & 27.4 & \\
\hline & Head \& Neck Oncology & 480 & 27.4 & \\
\hline & Sleep related & 24 & 1.4 & \\
\hline & Trauma & 3 & 0.2 & \\
\hline \multirow[t]{5}{*}{4} & Language of communication & & & \multirow{5}{*}{0.0001} \\
\hline & Hindi & 1613 & 92.1 & \\
\hline & English & 82 & 4.6 & \\
\hline & Punjabi & 54 & 3.1 & \\
\hline & Others & 2 & 0.1 & \\
\hline \multirow[t]{5}{*}{5} & Consultation type & & & \multirow{5}{*}{0.0001} \\
\hline & Emergency & 751 & 42.9 & \\
\hline & Urgent & 189 & 10.8 & \\
\hline & Semi-urgent & 361 & 20.6 & \\
\hline & Non-urgent & 450 & 25.7 & \\
\hline
\end{tabular}


positive for SARS-CoV-2 infection at some point during the lockdown of which 267 positive patients (42.3\%) were detected of COVID-19 through the TO. 1069 patients $(61.1 \%)$ were further called to hospital following the teleconsultation and 1562 patients $(89.2 \%)$ felt the follow up calls were easy.

Patient responses in English and Hindi were used for final validation of both the versions. Also the Hindi responses were translated to English for cumulative analysis of total sample size.

On final validation, the overall Cronbach's alpha coefficient was between 0.8 to 0.9 and intra-class correlation coefficient was $>0.75$ suggestive of good internal consistency and reliability of the questionnaire i.e., none of the nine items in patient satisfaction forum significantly altered the consistency of the instrument (Table 2).

On Exploratory factor analysis for English version, Hindi version and cumulative analysis of total sample for English version, the Kaiser-Meyer-Olkin test (KMO) of sampling was adequate $(\mathrm{KMO}=0.886,0.906$ and 0.908 respectively) and the Bartlett test of sphericity was significant (Chi-square, gl and $\mathrm{p}$ value $=2617.945,36$, $<0.001 ; 3518.098,36,<0.001 ; 5891.315,36,<0.001$ respectively), indicating that the items were appropriate for a factor analysis. One factor emerged with an eigenvalue greater than one (Table 2). The number of dimensions extracted were represented on the scree plot (Fig. 2). The above results reflect on the statistical robustness of the English and Hindi versions of the patient feedback questionnaire.

The effectiveness of the Otolaryngology telemedicine services during the lockdown period were assessed by comparing cumulative percentage of positive and negative response to each item. Approximately $65-75 \%$ of patients had positive response when compared to $8-14 \%$ patients having negative response and $12-25 \%$ having a neutral response as shown in Table 3. With regard to savings, 9.6\% opined for saving time in patient management, $18 \%$ opined for saving their frequency of travel, $31.9 \%$ opined for money savings and $31.6 \%$ opined for saving either two or three of above whereas $8.7 \%$ opined for not having saved any with use of TO.

On assessment of effectiveness of telemedicine service in terms of change in the health status of the patient, 1252 patients $(71.5 \%)$ experienced improvement to complete recovery with their ENT complaints, 352 patients $(20.1 \%)$ had no change with their complaints and 147 patients (8.4\%) experienced deterioration or worsening of their complaints despite utilising the TO services. On further probing the 147 patients who experienced worsening in the health status, death was noted in 29 patients $(19.7 \%)$ who belonged to Head and Neck oncology subspeciality contributing to a mortality rate of $1.65 \%$ in our study.
The questionnaire also included a patient suggestion forum where the patient/guardian were open to provide their suggestions to improve the TO facility. 62 patients $(3.5 \%)$ opined for difficulty in registration procedure attributed to the limited time of registration due to limited phone lines for registration at the administrative end and therefore suggested to increase the number of registration phone lines and the time allotted for the same.

\section{Discussion}

The validation of pilot questionnaire and the final questionnaire both in English and Hindi showed good reliability and acceptable level of validity. The five responses to each item of satisfaction questionnaire were graded on Likert scale which helped to optimize the discriminative power of each item as positive, negative and neutral. [10, 13] The internal consistency achieved was good with overall Cronbach's alpha for questionnaire and factor 1 above 0.808 and 0.886 for English and Hindi versions respectively. The results show that it was adequate to perform the factor analysis on which the questionnaire had only one dimension on patient satisfaction which accounted for a total variance of $45.7 \%$ and $52.9 \%$ for English and Hindi versions respectively (Table 2) [14].

Telemedicine services can be broadly categorized into remote communication technology based services, Live video conferencing, Mobile health services, Remote patient monitoring and Store-and-forward services [15]. The TO service at our institute implemented the mobile health technology. Android smart phones with installed and downloaded WhatsApp mobile application were provided to the otolaryngology resident doctors addressing the TO consultation [16]. Patients were preferably asked to register with their contact numbers linked to this mobile application.

Among the total patients seeking the TO, male preponderance was seen and patients between 3rd to 7 th decade utilized it. Registrations included patients from various states of India of which north Indian states around Chandigarh, a Union territory where the tertiary care institute is located, predominated as shown in Table 1. $10.6 \%$ patients were uneducated and needed assistance of a guardian to register with TO whereas $89.4 \%$ patients were educated and could manage availing it by themselves except for head and neck oncology patients on palliative care, elderly bedridden and long term tracheotomized patients. Thus, the literacy disparity did hinder the access to mobile health in our study akin to the study by Bailey et al. [17]

Consultations pertaining to Head and Neck oncology, oral cavity, larynx and pharynx were observed to be pre- 


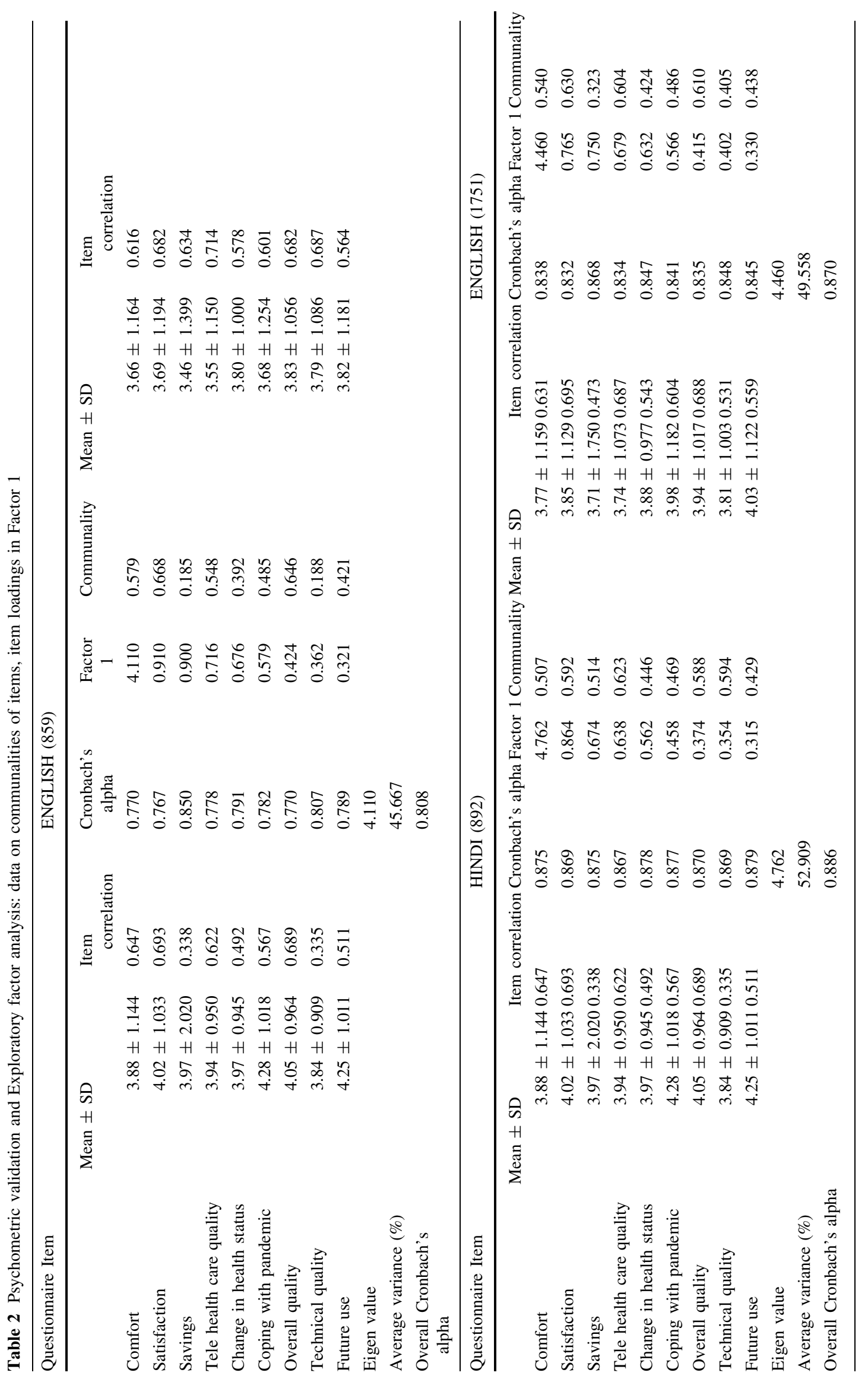


Fig. 2 Scree plot for questionnaire in a English b Hindi c English for 1751 sample
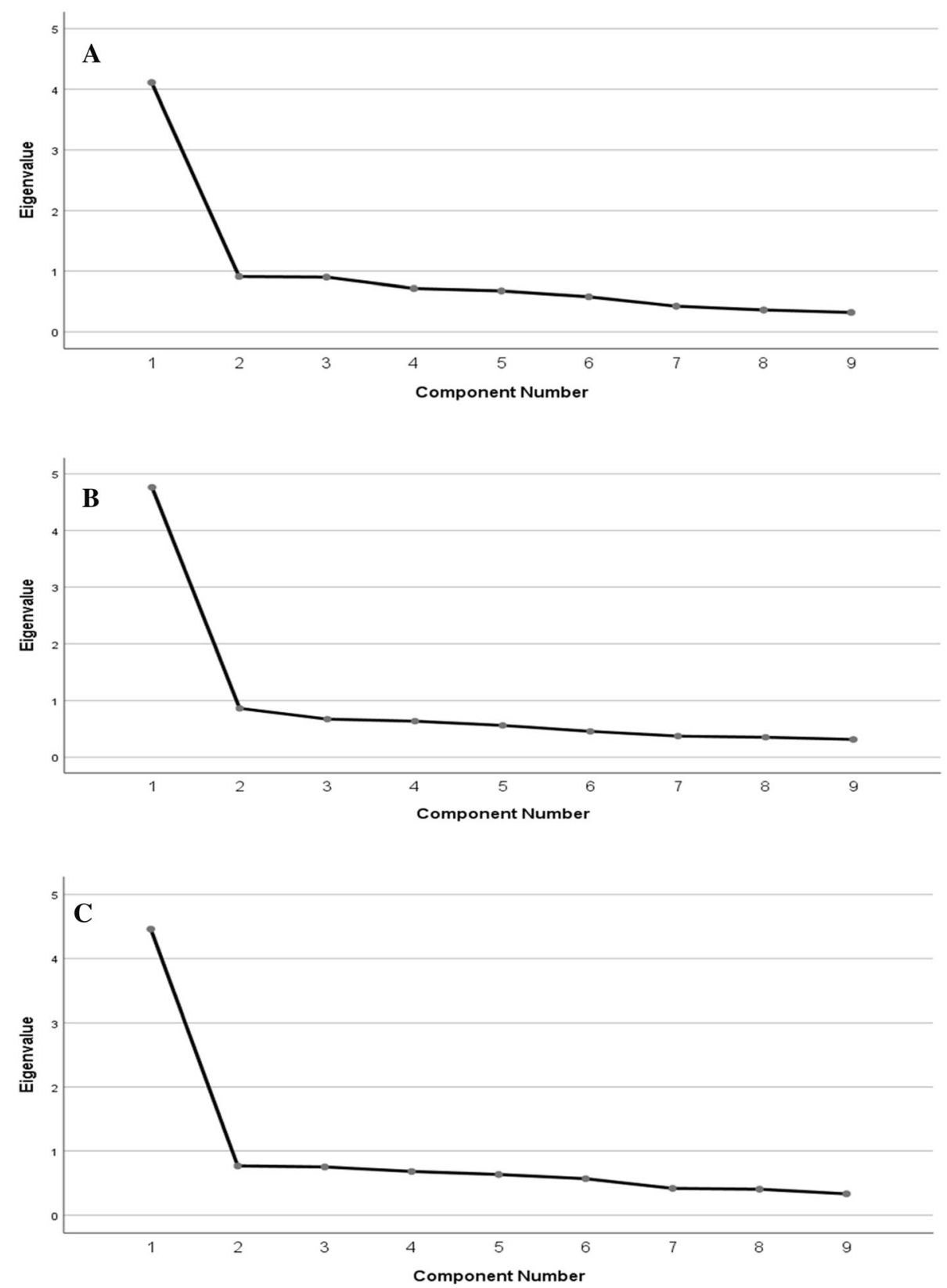

Table 3 Percentages of patient response for score 1 to 5 on questionnaire

\begin{tabular}{|c|c|c|c|c|}
\hline Questionnaire items & Cumulative $\%$ of score 1 and 2 & $\%$ of score 3 & Cumulative $\%$ of score 4 and 5 & Total \\
\hline Comfort & 14.6 & 17.3 & 68.1 & 100 \\
\hline Satisfaction & 13.7 & 13.8 & 72.5 & 100 \\
\hline Tele health care quality & 13.7 & 20.0 & 66.3 & 100 \\
\hline Change in health status & 8.4 & 20.1 & 71.5 & 100 \\
\hline Coping with pandemic & 11.9 & 17.7 & 70.4 & 100 \\
\hline Overall quality & 8.0 & 23.1 & 68.9 & 100 \\
\hline Technical quality & 9.8 & 24.5 & 65.7 & 100 \\
\hline Future use & 13.7 & 11.9 & 74.4 & 100 \\
\hline
\end{tabular}


eminent followed by Rhinology and Otology (Table 1). Due to ongoing routine emergency and triage services at the institute, the TO service did not deal with acute ENT emergencies and trauma cases. However, after immediate management of the emergency cases, patients were directed to be followed up with the TO. Type of consultation as opined by the patient/guardian included $42.9 \%$ emergency consultations of which genuine emergencies as assessed by the TO ENT clinician were redirected to the emergency services immediately on priority basis while some cases were allotted appointments for a doctor visit after adequate reassurance and conservative treatment till the visit. Elective consultations (urgent, semi-urgent and non-urgent) included the operated and non-operated follow up patients and new registrations. Depending upon the need for physical examination, otorhinolaryngological endoscopy procedures and aseptic dressings, $61.1 \%$ patients were directed either to nearest ENT setup or given appointment for a doctor visit at the institute according to the patient convenience. This data reflects on the effectiveness of mobile health in guidance provided for appropriate management.

Parameters like waiting time for successful registration, receiving call from the doctor after successful registration and clarity of communication were included in the questionnaire to reflect upon the technical constraints associated with TO [18]. In our study, 55.2\% patients spent more than 15 min for a successful registration in comparison to Rimmer et al. study in which the average waiting time was 10 min.[19] The factors causing atleast 15 min of waiting time for a successful registration in our study were (i) only $2 \mathrm{~h}$ of registration time allotted (ii) Limited phone lines provided by the telehealth administration and (iii) Network connectivity issues. Only $4.9 \%$ patients were not addressed on the day of registration and $2 \%$ had lack of clarity in communication due to connectivity issues at both the patient and clinician ends and were clarified once the network issues were fixed.

In our study of 1751 patients, $97.5 \%$ patients were able to incorporate the use of WhatsApp for a successful consultation. On using this mobile app, patients in whom a clinical photograph or a video recording would suffice an examination to avoid a doctor visit were requested to share them. As evidenced in previous studies, WhatsApp was effectively utilized in patient medical record and doctor prescription sharing [20]. Patient contacts were saved in these smart phones which helped the ENT clinicians in following up the patient effectively. Approximately $90 \%$ patients opined of ease in follow up calls due to utility of this mobile app. However, patients who did not have an access to a smart phone and/or WhatsApp on their smart phone $(2.45 \%)$ were dealt with by direct voice communication providing guidance and prescription by targeted text messages via the mobile phone which is also another mode of mobile health technology [15].

Although numerous telemedicine based remote COVID19 detection tools have been emerged, the telehealth administration at our institute did not incorporate any such tool for diagnosing the patients seeking TO of COVID-19 disease [21]. However, every registered patient was enquired of any symptoms and signs suggestive of SARS$\mathrm{CoV}-2$ infection and suspected patients were redirected to nearest COVID-19 evaluation centers for screening and testing. Out of the 630 patients who tested positive for SARS-CoV-2 infection at some point of time during the pandemic lockdown, $267(42.38 \%)$ patients received the guidance from TO clinicians for their symptoms akin of coronavirus disease to get tested. Common symptoms among the positive patients included sore throat, fever, myalgia, isolated anosmia and dysgeusia with or without a significant history of travel or exposure to a COVID-19 patient [22]. Mobile health had bridged the gap between patients and clinicians enabling the asymptomatic to practice social distancing and symptomatic to stay at home and communicate with the telehealth providers virtually reducing the spread of virus to mass populations and frontline health care workers [23]. Telehealth provided a forward triage to sort out patients before they arrive in the emergency department. However, we lacked in imbibing an automated screening algorithm and clinical management models for mobile health which would ease in identifying high risk and exposed cases [24].

The patient satisfaction forum on the questionnaire was the work horse of this study. The first item on satisfaction forum reflected upon the comfort/ease of use of the mobile health in discussing the complaints, sharing clinical photo or video clip with the clinician over a mobile app. [8] By asking to rate patient satisfaction in the second item and quality of tele-health care over regular health care in the fourth item, the usefulness of TO in addressing the disease without the need for direct doctor visit was assessed. The third item was a subjective analysis for savings achieved by the patient with the mobile health rather than a quantitative or an objective analysis in terms of comparison of cost incurred due to travel frequency of hospital visits and total time from first consultation to diagnosis and/or treatment between regular care and TO. $[25,26]$ The ultimate fate of the patient who utilized TO was reflected by enquiring on their health status in the fifth item. According to our study, the patients who experienced worsening and/or deterioration in their health status including deaths during the pandemic lockdown were the head and neck malignancy patients who were awaiting evaluation, those who were planned for an elective surgery and/or adjuvant treatments, those who developed recurrence of the malignancy and those who were chronically ill and on palliative care, 
concurrent to the literature review [27]. They were worst hit due to the non-functioning of the scheduled investigative, operative, definitive or adjuvant ablative treatments and palliative treatments at all government as well as private setups during the lockdown [28]. By enquiring on how the patient could cope up during the COVID-19 pandemic with the help of telemedicine facility in the sixth item, the role of TO in remote clinical assessment of COVID-19 and in providing appropriate guidance to seek the nearest COVID-19 management centers and also in educating the positive patients on home based care and quarantine measures. The seventh and eighth item analyzed the patient rating for overall and technical quality [13]. Willingness to use the mobile health again in future for themselves or for their family members was enquired on the ninth item of the questionnaire. $13.7 \%$ patients had negative response for the ninth item and requested upon resuming the regular services whereas $74.4 \%$ patients gave a positive response, of which $43.7 \%$ patients were willing to use the service as provided and $30.7 \%$ patients were willing for a future use with improvements. Most important suggestions were those pertaining to improving the logistic and technical problems faced in a successful registration [29].

Important limitations of our study included (i) the subspeciality wise effectiveness of the TO could not be done (ii) quantitative assessment of the patient savings in terms of time, frequency of visits and cost incurred was not done (iii) the clinical models were not redesigned to cater mobile health needs (iv) specific coding for out-patient, in-patient and follow up consultations was not incorporated (v) the ENT clinicians rendering TO and the investigators of this study had limited mobile health experience and did not receive any specific training or accreditation prior to initiation of TO (vi) estimation of TO registrations growth rate could not be done as the study was limited to 3 months duration and also the pandemic duration was not pre-defined at that point of time leading us to an uncertainty to what extent of time the TO would be in practice at the institute $[26,30]$. The best asset of our study is a statistically robust and fully validated and reliable patient feedback questionnaire in English and Hindi tested and applied to a large study population. This questionnaire can be utilized by any medical specialty practicing mobile health to evaluate its effectiveness during the COVID-19 era.

\section{Conclusion}

Mobile health, one of the most effortless and user-friendly modalities of telemedicine in practice had substantially addressed the Otolaryngology, Head and neck surgery services at our institute during the COVID-19 lockdown period. It was advantageous in offering the routine consultations, follow ups, guidance for elective procedures and priority-based management of malignancies. However, the head and neck oncology patients requiring palliative care did not benefit much out of this service. We developed a validated questionnaire for Tele-otolaryngology in English and Hindi languages which incorporated parameters assessing its effectiveness during COVID-19 pandemic. In view of ongoing pandemic restrictions and anticipated second wave of COVID-19 in India, telehealth has a significant role to play which can be safely and effectively practiced on routine basis with adequate staff deployment and training, coding the consultations and redesigning the technical as well as the management strategies.

Acknowledgements We acknowledge the contribution of Ms. Manognya Mallavarapu, CIMA (Adv. Dip. MA) in providing technical support related to the data analysis.

Funding Not applicable.

\section{Declarations}

Conflict of interest The authors declare that there is no conflict of interest.

Ethics Approval Institutional ethics committee approval was taken prior to beginning of the study with approval number "NK/6817/ Study/185".

Consent to Participate A verbal consent of the patient and/or their guardian was taken following which the investigator proceeded in procuring their feedback to the questionnaire.

Consent for Publication A verbal Consent was taken for use of patient's treatment related data for academic use and publication on the condition of anonymity.

\section{Appendix}

\section{ANNEXURE I: Pilot Questionnaire}


POSTGRADUATE INSTITUTE OF MEDICAL EDUCATION AND RESEARCH, CHANDIGARH, INDIA

\section{PATIENT FEEDBACK QUESTIONNAIRE FOR TELE-OTOLARYNGOLOGY}

Basic Information

1.Name/ Age/ Sex/

2.Mobile Number

3. State

4.Highest Educational Qualification- i. Post Graduate ii. Graduate iii. Senior Secondary iv. Matric v. Schooling vi. Does not apply

5.Sub Speciality- i. Ear ii. Nose iii. Throat iv. Head \& Neck v. Sleep related vi. Trauma.

Access To Care

1.Waiting Time Before A Successful Registration -

$<15$ Minutes

$>15$ Minutes

2.Were Further Follow-Up Calls Made Easy? Yes/ No

Communication \& Information

1.Did You Receive A Call After Registration? Yes/ No

If No, How Was The Issue Solved?

2.Was Communication With Doctors Clear? Yes/ No

3.Language Mainly Used For Communication
i. Hind
ii. English
iii. Punjabi
iv. Others

4.What Was The Type Of Your Consultation?
i. Emergency
ii. Urgent
iii. Semi-Urgent
iv. Non-Urgent

5.Was Whatsapp Used For Exchange Of Reports / Scans / Clinical Picture / Video / Final

Prescription? Yes / No

6.Were You Called To The Ward For Examination/Admission? Yes/ No

If Yes, What Was The Final Fate?

7.Did Your Consultation Help You Get Detected Of Covid-19 ? Yes / No

Patient Satisfaction Information

(i) How Comfortable Were You Discussing Your Problems On Phone Than In-Person ?

1.Very Uncomfortable 2.Uncomfortable 3.Neutral 4.Comfortable 5.Very Comfortable.

(ii) How Satisfied Were You With Tele-Consultation Without Physical Examination ? 1.Very Unsatisfied 2.Unsatisfied 3.Neutral 4.Satisfied 5.Very Satisfied

(iii) How Comfortable Were You In Sharing Your Clinical Picture Or Video Calling With The Doctor?

1.Very Uncomfortable 2.Uncomfortable 3.Neutral 4.Comfortable 5.Very Comfortable

(iv) How Satisfied Were You With Exchange Of Medical Records, Reports And Final Prescription Between You And The Doctor?

1.Very Unsatisfied 2.Unsatisfied 3.Neutral 4.Satisfied 5.Very Satisfied

(v) Did Tele-Consultation Help You Save Your Time / Frequency Of Travel / Money ?

1.None 2.Saved Time Only 3.Saved Frequency Of Travel Only

4.Saved Money Only 5.Saved All Three

(vi) How Do You Rate Overall Quality Of Tele-Consultation?

1.Worst 2.Poor 3.Fair 4.Good 5.Excellent

(vii) How Do You Rate Technical Quality Of Tele-Consultation?

1.Worst 2.Poor 3.Fair 4.Good 5.Excellent

(viii) How Do You Rate The Quality Of Health Care Delivered By Tele-Consultation When Compared To Regular Services?

1.Worse 2.Bad 3.Not Sure 4.Same 5.Better

(ix) How Did The Tele-Consultation Service Change The Status Of Patient Health ? 1.Worsened 2.Deteriorated 3.No Change 4.Improved 5.Recovered

(x) Did This Facility Help You To Cope Up With Covid-19 Pandemic? 1.Not In Anyway 2.Not Sure 3.May Be 4.Yes, Partially 5.Yes, Completely

(xi) Would You Like To Use This Service Again? 


\section{ANNEXURE II: Validated English Questionnaire}

\section{POSTGRADUATE INSTITUTE OF MEDICAL EDUCATION \& RESEARCH, CHANDIGARH, INDIA PATIENT FEEDBACK OUESTIONNAIRE FOR TELE-OTOLARYNGOLOGY}

\begin{tabular}{|c|c|c|c|c|c|}
\hline Name & Age & \multicolumn{2}{|c|}{ Gender Male Female } & \multicolumn{2}{|l|}{ State } \\
\hline \multicolumn{6}{|c|}{ Educational Qualification 1.Postgraduate 2.Graduate 3.Senior Secondary 4.Matric 5.Schooling 6.Not applicable } \\
\hline \multicolumn{6}{|c|}{ Sub-Speciality 1.Ear 2 .Nose 3 .Oral cavity \& Throat 4 .Head and Neck cancers 5 . Sleep related 6 .Trauma } \\
\hline \multicolumn{6}{|c|}{ Waiting time for successful registration? $\quad$ 1.Less than 15 minutes 2. More than 15 minutes } \\
\hline \multicolumn{2}{|c|}{ Was call received after registration? 1 .Yes 2 . No } & \multicolumn{4}{|c|}{ Was communication with doctors clear? 1 .Yes 2 . No } \\
\hline \multicolumn{6}{|c|}{ Language used for communication? 1 .Hindi 2.English 3.Punjabi 4.Others, please specify } \\
\hline \multicolumn{6}{|c|}{ Type of Consultation 1.Emergency 2.Urgent 3.Semi-urgent 4.Non-urgent } \\
\hline \multicolumn{6}{|c|}{ Was WhatsApp used for exchange of medical records/reports/clinical photo/video/prescription? 1 .Yes 2 .No } \\
\hline \multicolumn{2}{|c|}{$\begin{array}{l}\text { Were you called to the hospital for further manage- } \\
\text { ment? } 1 \text {.Yes } 2 \text {.No }\end{array}$} & \multicolumn{4}{|c|}{ Were Follow-up calls easy? 1.Yes 2.No } \\
\hline \multicolumn{6}{|c|}{$\begin{array}{l}\text { Did you test positive for COVID-19? } 1 \text {.Yes } 2 . \text { No. } \\
\text { If Yes, did this consultation help you in getting detected of COVID-19 disease? } 1 \text {.Yes } 2 . \text { No }\end{array}$} \\
\hline $\begin{array}{l}\text { 1.Rate your comfort (discussing } \\
\text { your problem, sharing your clini- } \\
\text { cal photo/video on phone) }\end{array}$ & $\begin{array}{c}1 \\
\text { Very } \\
\text { uncomfortable } \\
\end{array}$ & $\stackrel{2}{\text { Uncomfortable }}$ & $\begin{array}{c}3 \\
\text { Neutral }\end{array}$ & $\stackrel{4}{\text { Comfortable }}$ & $\begin{array}{c}\mathbf{5} \\
\text { Very } \\
\text { comfortable } \\
\end{array}$ \\
\hline $\begin{array}{l}\text { 2.Rate your satisfaction (doctor } \\
\text { consultation \& advice without } \\
\text { physical examination) }\end{array}$ & $\stackrel{1}{\text { Very unsatisfied }}$ & $\stackrel{2}{2}$ Unsatisfied & $\begin{array}{c}3 \\
\text { Neutral }\end{array}$ & $\stackrel{4}{4}$ Satisfied & $\stackrel{5}{\text { Very satisfied }}$ \\
\hline $\begin{array}{l}\text { 3.Rate your savings with this } \\
\text { service }\end{array}$ & $\begin{array}{c}1 \\
\text { None }\end{array}$ & $\underset{\text { Time }}{2}$ & $\begin{array}{c}3 \\
\text { Travel }\end{array}$ & $\begin{array}{c}4 \\
\text { Money }\end{array}$ & $\begin{array}{c}\mathbf{5} \\
\text { Any } 2 / 3\end{array}$ \\
\hline $\begin{array}{l}\text { 4. Rate the quality of tele-health } \\
\text { care over the regular health care }\end{array}$ & 1 & 2 & 3 & 4 & 5 \\
\hline $\begin{array}{l}\text { 5.How did this facility change the } \\
\text { health status of the patient? }\end{array}$ & $\begin{array}{c}1 \\
\text { Worsened }\end{array}$ & $\stackrel{2}{2}$ & $\begin{array}{c}\text { 3 } \\
\text { No } \\
\text { change }\end{array}$ & $\begin{array}{c}\mathbf{4} \\
\text { Improved }\end{array}$ & $\begin{array}{c}\mathbf{5} \\
\text { Recovered }\end{array}$ \\
\hline $\begin{array}{l}\text { 6.Did this facility help you cope- } \\
\text { up with COVID-19 pandemic? }\end{array}$ & $\begin{array}{c}1 \\
\text { No }\end{array}$ & $\begin{array}{c}2 \\
\text { May be }\end{array}$ & $\begin{array}{c}3 \\
\text { Not sure } \\
\end{array}$ & $\begin{array}{c}\mathbf{4} \\
\text { Yes, partially } \\
\end{array}$ & $\begin{array}{c}\mathbf{5} \\
\text { Yes, } \\
\text { completely }\end{array}$ \\
\hline $\begin{array}{l}\text { 7.Rate the overall quality of } \\
\text { tele-consultation service }\end{array}$ & 1 & 2 & 3 & 4 & 5 \\
\hline $\begin{array}{l}\text { 8.Rate the technical quality of } \\
\text { tele-consultation service }\end{array}$ & 1 & 2 & 3 & 4 & 5 \\
\hline $\begin{array}{l}\text { 9.Would you like to use this ser- } \\
\text { vice again? }\end{array}$ & $\begin{array}{c}1 \\
\text { No }\end{array}$ & $\stackrel{2}{2}$ May be & $\begin{array}{l}3 \\
\text { Not sure }\end{array}$ & $\begin{array}{c}\mathbf{4} \\
\text { Yes, with } \\
\text { improvement }\end{array}$ & $\begin{array}{l}\mathbf{5} \\
\text { Yes, the way it } \\
\text { is provided }\end{array}$ \\
\hline
\end{tabular}


ANNEXURE III: Validated Hindi Questionnaire

\section{स्नातकोत्तर चिकित्सा शिक्षा एवं अनुसंधान संस्थान, चंडीगढ़, भारत टेली-ईएनटी के लिए रोगी प्रतिक्रिया प्रश्नावली}

\begin{tabular}{|c|c|c|c|c|c|}
\hline नाम & आयु & \multicolumn{2}{|c|}{\begin{tabular}{ll|l} 
लिग नर माहला & राज्य \\
\end{tabular}} & \multicolumn{2}{|l|}{ राज्य } \\
\hline शैक्षिक योग्यता & 2. स्रातक & 3.उच्च माध्यमिक & 4.मैट्रिक & \multicolumn{2}{|c|}{ 6. लागू नहीं } \\
\hline \multicolumn{2}{|c|}{$\begin{array}{llll}\text { उप-विशेषता } & \text { 1.कान } & \text { 2.नाक } & \text { 3.मुंह और गला }\end{array}$} & \multicolumn{2}{|c|}{ 4.सिर और गर्दन का कैंसर } & \multicolumn{2}{|c|}{ 6.चोट संबंधी } \\
\hline \multicolumn{3}{|c|}{ सफल पंजीकरण के लिए प्रतीक्षा समय? 1.15 मिनट से कम } & \multicolumn{2}{|c|}{2.15 मिनट से अधिक } & \\
\hline \multicolumn{2}{|c|}{ पंजीकरण के बाद कॉल मिला था? 1.हाँ 2 2. नहीं } & \multicolumn{4}{|c|}{ डॉक्टरों के साथ संचार स्पष्ट था? 1.हाँ 2.नहीं } \\
\hline \multicolumn{6}{|c|}{ 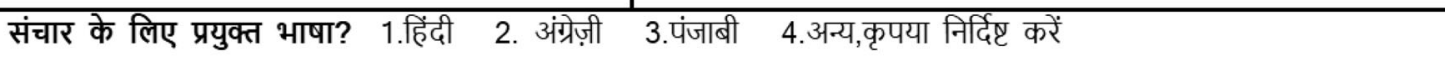 } \\
\hline \multirow{2}{*}{\multicolumn{6}{|c|}{$\begin{array}{l}\text { परामर्श का प्रकार } \\
\text { 1.आपातकालीन }\end{array}$}} \\
\hline & & & & & \\
\hline \multicolumn{2}{|c|}{$\begin{array}{l}\text { क्या आपको आगे के प्रबधन के लिए अस्पताल } \\
\text { बुलाया गया था? } \\
\begin{array}{llll} & \text { 1.हाँ } & \text { 2.नहीं } & \end{array}\end{array}$} & \multicolumn{3}{|c|}{ अनुवर्ती कॉल आसान थे? 1.हाँ 2 2.नहीं } & \\
\hline \multicolumn{6}{|c|}{$\begin{array}{l}\text { क्या आपने COVID-19 के लिए सकारात्मक परीक्षण किया? 1.हाँ } \\
\text { यदिहीं } \\
\text { यदि हाँ, तो क्या इस परामर्श ने आपको COVID-19 रोग का पता लगाने में मदद की? }\end{array}$} \\
\hline $\begin{array}{l}\text { 1. अपने आराम का मूल्यांकन करें } \\
\text { (अपनी समस्या पर चर्चा करना, अपनी } \\
\text { नैदानिक तस्वीर / वीडियो फोन पर } \\
\text { साझा करना) }\end{array}$ & $\begin{array}{l}1 \\
\text { बेहद } \\
\text { असुविधाजनक }\end{array}$ & $\begin{array}{l}2 \\
\text { असुविधाजनक }\end{array}$ & $\begin{array}{c}3 \\
\text { तटस्थ }\end{array}$ & $\begin{array}{l}\mathbf{4} \\
\text { आरामदायक }\end{array}$ & $\begin{array}{l}\mathbf{5} \\
\text { बेहद } \\
\text { आरामदायक }\end{array}$ \\
\hline $\begin{array}{l}\text { 2.अपनी सतुष्टि का मूल्याकन करे } \\
\text { (चिकित्सक परामर्श और शारीरिक } \\
\text { परीक्षा के बिना सलाह) }\end{array}$ & $\begin{array}{c}1 \\
\text { बहुत असंतुष्ट }\end{array}$ & $\begin{array}{l}2 \\
\text { असंतुष्ट }\end{array}$ & $\begin{array}{c}3 \\
\text { तटस्थ }\end{array}$ & $\begin{array}{l}4 \\
\text { संतुष्ट }\end{array}$ & $\begin{array}{c}\mathbf{5} \\
\text { बहुत संतुष्ट }\end{array}$ \\
\hline 3.इस सेवा के साथ अपनी बचत करें & कोई नहीं & समय & $\begin{array}{l}3 \\
\text { यात्रा }\end{array}$ & $\begin{array}{l}4 \\
\text { धन }\end{array}$ & $\begin{array}{l}\mathbf{5} \\
\text { कोई भी दो या } \\
\text { तीन }\end{array}$ \\
\hline $\begin{array}{l}\text { 4. नियमित स्वास्थ्य देखभाल पर टेली- } \\
\text { स्वास्थ्य देखभाल की गुणवत्ता की दर }\end{array}$ & 1 & 2 & 3 & 4 & 5 \\
\hline $\begin{array}{l}\text { 5.इस सुविधा ने रोगी की स्वास्थ्य } \\
\text { स्थिति को कैसे बदल दिया? }\end{array}$ & $\begin{array}{l}1 \\
\text { बहुत खराब हो } \\
\text { गई }\end{array}$ & बिगड़ गई & $\begin{array}{l}\text { कोई } \\
\text { परिवर्तन } \\
\text { नहीं }\end{array}$ & $\begin{array}{c}4 \\
\text { सुधारा हुआ }\end{array}$ & $\begin{array}{l}\mathbf{5} \\
\text { स्वास्थ्य ठीक हो } \\
\text { गया }\end{array}$ \\
\hline $\begin{array}{l}\text { 6.क्या यह सुविधा आपको COVID-19 } \\
\text { महामारी से निपटने में मदद करती है }\end{array}$ & $\begin{array}{l}1 \\
\text { नहीं }\end{array}$ & $\begin{array}{l}2 \\
\text { हो सकता है }\end{array}$ & $\begin{array}{l}\text { निश्चित } \\
\text { नहीं है }\end{array}$ & $\begin{array}{l}4 \\
\text { हाँ, आंशिक } \\
\text { रूप से }\end{array}$ & हाँ, पूरी तरह से \\
\hline $\begin{array}{l}\text { 7.टेली-परामर्श सेवा की समग्र गुणवत्ता } \\
\text { का मूल्यांकन करें }\end{array}$ & 1 & 2 & 3 & 4 & 5 \\
\hline $\begin{array}{l}\text { 8.टेली-परामर्श सेवा की तकरनीकी } \\
\text { गुणवत्ता का मूल्यांकन करें }\end{array}$ & 1 & 2 & 3 & 4 & 5 \\
\hline $\begin{array}{l}\text { 9.क्या आप फिर से इस सेवा का } \\
\text { उपयोग करना चाहते हैं? }\end{array}$ & 1 नहीं & $\begin{array}{l}2 \\
\text { हो सकता है }\end{array}$ & $\begin{array}{l}\text { निश्चित नहीं } \\
\text { है }\end{array}$ & $\begin{array}{l}\text { हाँ, सुधार के } \\
\text { साथ }\end{array}$ & $\begin{array}{l}\mathbf{5} \text { हिस } \\
\text { हां, यह जिस } \\
\text { तरह से प्रदान } \\
\text { किया गया है }\end{array}$ \\
\hline
\end{tabular}




\section{References}

1. Ekeland AG, Bowes A, Flottorp S (2010) Effectiveness of telemedicine: a systematic review of reviews. Int $\mathrm{J}$ med Inform 79:736-771

2. Ohannessian R, Duong TA, Odone A (2020) Global telemedicine implementation and integration within health systems to fight the COVID-19 pandemic: a call to action. JMIR Public Health Surveill 6(2):e18810

3. Chao GF, Li KY, Zhu Z, McCullough J, Thompson M, Claflin J, et al. Use of Telehealth by surgical specialties during the COVID19 pandemic. JAMA Surg. Epub ahead of print 26 March 2021 DOI:https://doi.org/10.1001/jamasurg.2021.0979.

4. Moentmann MR, Miller RJ, Chung MT, et al. Using telemedicine to facilitate social distancing in otolaryngology: a systematic review. J Telemed Telecare. 3 Feb 2021 DOI: https://doi.org/10.1177/1357633X20985391.

5. Yip MP, Chang AM, Chan J et al (2003) Development of the telemedicine satisfaction questionnaire to evaluate patient satisfaction with telemedicine: a preliminary study. J Telemed Telecare 9:46-50

6. Demiris G, Speedie S, Finkelstein S (2000) A questionnaire for the assessment of patients' impressions of the risks and benefits of home telecare. J Telemed Telecare 6:278-284

7. Demiris G, Speedie SM, Finkelstein S (2001) Change of patients' perceptions of telehome care. Telemed J E Health 7:241-248

8. Parmanto B, Lewis AN, Graham KM et al (2016) Development of the telehealth usability questionnaire (TUQ). Int J Telerehabil 8(1):3-10

9. Rattray J, Jones MC (2007) Essential elements of questionnaire design and development. J Clin Nurs 16:234-243

10. Jamieson, S. "Likert scale". Encyclopedia Britannica, 27 Sep. 2017, https://www.britannica.com/topic/Likert-Scale (2017). Accessed 1 Apr 2021

11. Portney LG, Watkins MP (2009) Foundations of clinical research: Application to practice, 3rd edn. Prentice Hall, Upper Saddle River

12. Ware JE, Gandek B (1998) Methods for testing data quality, scaling assumptions, and reliability: the IQOLA Project approach. J Clin Epidemiol 51:945-952

13. Vidal-Alaball J, Mateo GF, Domingo JLG et al (2020) Validation of a short questionnaire to assess healthcare professionals' perceptions of asynchronous telemedicine services: the Catalan version of the health optimum telemedicine acceptance questionnaire. Int J Environ Res Public Health 17:2202

14. Argimon-Pallàs JM, Mateo FG, Jiménez-Villa J et al (2010) Psychometric properties of a test in evidence based practice: the Spanish version of the Fresno test. BMC Med Educ 10:45

15. Center for Connected Health Policy. About telehealth (2020) https://www.cchpca.org/about/about-telehealth/livevideosynchronous. Accessed 1 Apr 2021
16. Giansanti D (2020) WhatsApp in mHealth: an overview on the potentialities and the opportunities in medical imaging. mHealth 6: 19.

17. Bailey SC, O'Conor R, Bojarski EA et al (2014) Literacy disparities in patient access and health-related use of internet and mobile technologies. Health Expect 18(6):3079-3087

18. Simmons S, Alverson D, Poropatich R et al (2008) Applying telehealth in natural and anthropogenic disasters. Telemed J E Health 14:968-971

19. Rimmer RA, Christopher V, Falck A et al (2018) Telemedicine in otolaryngology outpatient setting-single center head and neck surgery experience. Laryngoscope 128(9):2072-2075

20. Giordano V, Koch H, Godoy-Santos A et al (2017) WhatsApp messenger as an adjunctive tool for telemedicine: an overview. Interact J Med Res 6(2):e11

21. Lukas H, Xu C, Yu Y et al (2020) Emerging telemedicine tools for remote COVID-19 diagnosis, monitoring, and management. ACS Nano 14:16180-16193

22. Krajewska J, Krajewski W, Zub K et al (2020) COVID-19 in otolaryngologist practice: a review of current knowledge. Eur Arch Otorhinolaryngol 277(7):1885-1897

23. Monaghesh, E, Hajizadeh A (2020) The role of telehealth during COVID-19 outbreak: a systematic review based on current evidence. BMC Public Health 20(1): 1193

24. Hollander JE, Carr BG (2020) Virtually perfect? Telemedicine for Covid-19. N Engl J Med 382:1679-1681

25. Urquhart AC, Antoniotti NM, Berg RL (2011) Telemedicine-an efficient and cost-effective approach in parathyroid surgery. Laryngoscope 121(7):1422-1425

26. Miller LE, Rathi VK, Kozin ED et al (2020) Telemedicine services provided to medicare beneficiaries by otolaryngologists between 2010 and 2018. JAMA Otolaryngol Head Neck Surg 146(9):816-821

27. Singh HK, Patil V, Ganne C et al (2020) Preparedness of the cancer hospitals and changes in oncosurgical practices during COVID-19 pandemic in India: za cross-sectional study. J Surg Oncol 122(7):1276-1287

28. Büntzel J, Walter S, Hellmund H et al (2021) Oncology services for patients with head and neck cancer during corona-times-Patients' perspective. Laryngorhinootologie 100(2):104-110

29. Chen $\mathrm{G}, \mathrm{Wu} \mathrm{Q}$, Jiang $\mathrm{H}$ et al (2020) Impact of treatment delay due to the pandemic of COVID-19 on the efficacy of immunotherapy in head and neck cancer patients. J Hematol Oncol 13(1):174

30. Smith AC, Thomas E, Snoswell CL et al (2020) Telehealth for global emergencies: Implications for coronavirus disease 2019 (COVID-19). J Telemed Telecare 26(5):309-313

Publisher's Note Springer Nature remains neutral with regard to jurisdictional claims in published maps and institutional affiliations. 